\title{
Clinical Impact and Healthcare Resource Utilization Associated with Early versus Late COPD Diagnosis in Patients from UK CPRD Database [Corrigendum]
}

Kostikas K, Price D, Gutzwiller FS, et al. Int J Chron Obstruct Pulmon Dis. 2020;15:1729-1738.

On page 1730 in Patients and Methods, Study Design section, and on page 1736 Ethics Approval section, the
ISAC number reported was incorrect. The correct number is ISAC 17_118.

The authors apologize for this error.

\section{Publish your work in this journal}

The International Journal of COPD is an international, peer-reviewed journal of therapeutics and pharmacology focusing on concise rapid reporting of clinical studies and reviews in COPD. Special focus is given to the pathophysiological processes underlying the disease, intervention programs, patient focused education, and self management protocols. This journal is indexed on PubMed Central, MedLine and CAS. The manuscript management system is completely online and includes a very quick and fair peer-review system, which is all easy to use. Visit http://www.dovepress.com/testimonials.php to read real quotes from published authors. 